\title{
Factors That Influence Access To Credit For Micro, Small, And Medium-Sized Enterprises In Ruiru Sub County In Kenya
}

\author{
Samson Manjuru Mburu *, Dr. Lucy Wanjiru Njogu ** \\ * Student, Jomo Kenyatta University of Agriculture and Technology, Kenya \\ ** Ph.D., Lecturer, College of Human Resource Development (COHRED), Jomo Kenyatta University of Agriculture and Technology, Kenya
}

DOI: 10.29322/IJSRP.11.11.2021.p11918

http://dx.doi.org/10.29322/IJSRP.11.11.2021.p11918

\begin{abstract}
The study's general objective was to establish the factors that influence access to credit for MSMEs in Ruiru Sub County. Specifically, the study set out to determine the influence of cost of credit, financial information asymmetry, type of lending institution, and credit reference bureau on access to credit for MSMEs in Ruiru Sub County in Kenya. The study adopted a descriptive research design. The target population was 590 MSMEs registered for operations in Ruiru Sub County for the year 2021. The study employed a probability sampling design. The data was collected using a closed-ended questionnaire administered to a randomly selected sample of 238 respondents from the target population comprising 590 registered MSMEs for the year ending 2021. The data collected was edited, coded, classified, tabulated, and analyzed using SPSS. Non- parametric data analysis techniques of ordinal regression and Spearman correlation were performed. There was a high correlation between all the independent variables and dependent variable access to credit. Cost of credit was not a significant negative predictor, financial information asymmetry was a significant positive predictor, the type of financial lending institution was a significant positive estimator, and credit reference bureau was a significant positive predictor of access to credit. The study recommended that credit reference bureaus be restructured to suit the emerging economy's needs of Kenya, financial institutions to customize their credit products to specific target markets, both parties' partisan to credit transaction to practice full disclosure practices, financial institutions to provide more financial training, and financial institutions to work towards reducing the cost of credit.
\end{abstract}

Index Terms- Cost of credit, access to credit, financial information asymmetry, type of financial Institution, credit reference bureau

\section{INTRODUCTION}

A ccess to financial services has been identified as one of the means of creating employment, reducing poverty, and promoting growth (Ndungu, 2016). Micro, Small, and Medium Enterprises (MSMEs) play a very significant role in the economy of any country, both developing and developed nations and individuals. Silong and Gadanakis (2020) note that MSMEs play a crucial role in creating dynamic market-oriented economic growth, employing the growing workforce, alleviating poverty, and promoting democratization in developing countries.

In recent times MSMEs have been lauded for contributing to grassroots economic growth and equitable, sustainable development. MSMEs have a significant contribution to the national economy. Specifically, MSMEs contribution to Gross domestic product (GDP) has recorded increases through time, showing a gradual increase from 1993 to 2018 (World Bank, 2019a). MSMEs need access to credit to cover operational costs and for their growth and expansion.

World Bank (2020) shows that close to $68 \%$ of Kenyan MSMEs state access to finance as a challenge. World Bank (2020) reports that approximately $70 \%$ of all MSMEs in developing markets lack access to credit, making it difficult for them to survive.

According to World Bank (2020), the credit gap varies significantly between regions and countries and is particularly wide in Asia and Africa. The credit access gap for formal MSMEs was estimated at US\$ 1.2, while that for the informal sector, MSMEs stood at the U.S. \$ 1.4 trillion (World Bank, 2020). Therefore, enhancing credit access to MSMEs will improve their capability to be established and thrive, expand governments' development and growth, and increase employment opportunities.

\subsection{Statement of the problem}

Kenya aims to transform into a newly industrializing middleincome country by 2030 as laid out in the country's development blueprint covering the period 2008 to 2030 (GOK, 2007). To achieve this goal, one of its focuses is encouraging the growth of the Micro, Small, and Medium Enterprises (MSMEs), leading to the formation of the Micro and Small Enterprises Authority (MSEA). MSEA is a state corporation established under the Micro and Small Enterprise Act No. 55 of 2012, capable of contributing to the industrializing goal by 2030 (GOK, 2012).

According to the African Development Bank and Government of Kenya (2018), MSMEs contribute to $40 \%$ of Kenya's GDP, making the sector a significant contributor to socioeconomic development. MSMEs require finance for expansion, productivity, and growth, yet the majorities self-finance their businesses (Kenya Institute for Public Policy Research Analysis (KIPPRA), 2020). Analysis of the World Bank Enterprise Survey Data 2019 suggests that close to $68 \%$ of Kenyan enterprises state access to finance as a challenge. According to the Survey, $50 \%$ of 
Kenyan MSMEs have never approached a bank, and only $36 \%$ of Kenya's MSMEs have accessed loans, compared to the OECD average of $51 \%$ (World Bank, 2019b)

Lack of capital is still the most significant constraint to MSMEs growth in Kenya. The lack of money inhibits MSMEs' capability to create jobs, pay taxes and provide goods and services. Despite a landscape of service providers, including nine microfinance banks, 23 credit-only MFIs, and 43 banks, there are critical gaps in serving different MSME segments, especially the enterprises in the missing middle that are too big for microfinance and too small for private equity and debt (Kenya National Bureau of Statistics (KNBS), 2018). The report further adds that MSMEs are still struggling with the gap in funding between microloans and more extensive commercial lending. Governments, NGOs, and the private sector in Kenya attempt to fund that gap but only cater to a small market share.

Despite increased efforts to lend to MSMEs, financial inclusion analysis indicates that there is a total credit gap of over US\$ 5bn for MSMEs in Kenya (World Bank, 2020). If this persists, the industrialization goal of vision 2030 will fall due. The credit gap creates a need to investigate why there is a persistent lack of access to credit despite all the stakeholder's efforts to overcome the perennial problem of access to finance.

There is extensive literature on factors that influence access to credit for MSMEs, mainly from the developed economies whose applicability in an emerging economy is practically impossible. In addition, there exists a gap in the existing knowledge on the determinants of the cost of credit, financial information asymmetry, type of financial lending institution, and credit reference bureau. Therefore, this study will fill this gap by providing relevant evidence from MSMEs in Ruiru Sub County for 2021 in Kenya, an emerging economy.

\subsection{Objectives}

\subsubsection{General Objective}

The study's general objective was to determine the factors that influence access to credit for MSMEs in Ruiru Sub County in Kenya.

\subsubsection{Specific Objectives}

The study specifically aimed:

i. To determine the influence of cost of credit on access to credit for MSMEs in Ruiru Sub County in Kenya.

ii. To determine the influence of financial information asymmetry on access to credit for MSMEs in Ruiru Sub County in Kenya.

iii. To determine the influence of the type of financial lending institution on access to credit for MSMEs in Ruiru Sub County in Kenya.

iv. To determine the influence of the credit reference bureau on access to credit for MSMEs in Ruiru Sub County in Kenya.

\subsection{Research Question}

The following research questions guided the study:
1. What was the influence of cost of credit on access to credit for MSMEs in Ruiru Sub County in Kenya?

2. What was the influence of financial information asymmetry on access to credit for MSMEs in Ruiru Sub County in Kenya?

3. What was the influence of the type of financial lending institution on access to credit for MSMEs in Ruiru Sub County in Kenya?

4. What was the influence of the credit reference bureau on access to credit for MSMEs in Ruiru Sub County in Kenya?

\section{LITERATURE REVIEW}

\subsection{Theoretical background to the study \\ 2.2.1 Credit Rationing Theory}

Credit rationing Theory by Stiglitz \& Weiss (1981) is among the most critical theories that focus on financing gap analysis. Stiglitz \& Weiss (1981) note that lenders seek to impose quantitative restrictions on the amount of loan the borrower can obtain, a state referred to as equilibrium quantity rationing of credit, since high-interest rates may give additional impetus to adverse selection and risk-taking. According to Kweyu (2017), the model is based on imperfect markets characterized by information asymmetry, making it costly for financial institutions to obtain accurate information on the MSMEs (borrowers) and monitor their actions.

\subsubsection{Information Asymmetry Theory}

The theory of information asymmetry developed in the 1970s and 1980s was attributed to Akerlof's (1970) paper: The Market for lemons, quality uncertainty, and the market mechanism. It postulates that an imbalance of information between two parties transacting can lead to inefficient outcomes. This imbalance can cause one party to enter into a transaction or make costly decisions.

\subsubsection{Financial Intermediation Theory}

The theory of financial intermediation, according to Andries and Cuza (2009), describes the process where savers (surplus units) give funds through deposits to intermediaries (financial institutions) who in turn channel out the funds to the borrowers or spenders (deficit units). Andries and Cuza (2009) observe that financial intermediation refers to transferring funds from the entities with surplus to entities experiencing deficit through financial intermediaries. Ndungu (2017) noted that financial intermediaries are financial institutions specializing in purchasing and selling financial capital.

\subsubsection{Adverse Selection Theory}

According to Stigliz and Weiss (1981), the adverse selection theory is based on two assumptions. The two assumptions postulate that lenders fail to distinguish between borrowers of different risks, and loan contracts are subject to limited liability if project returns are less than debt obligations. The borrower bears no responsibility for honoring the end of their bargain. This analysis applies to involuntary default and assumes that borrowers repay loans when they have the means to do so.

\subsection{Conceptual Framework}

\subsubsection{Cost of Credit}


Cost of credit refers to all the money involved in acquiring credit from the lending financial institutions, namely SACCOs, microfinance institutions, and Commercial banks (Chirchir, 2017). The cost of credit is indicated by legal fees, processing, and interest charged on loans, negotiation fees, travel costs, insurance, collaterals to acquire loans, and any charge related to accessing credit (Chirchir, 2017).

\subsubsection{Financial Information Asymmetry}

The concept of information asymmetry was attributed to Akerlof (1970). Two parties to a single transaction possess different knowledge concerning the same trade; hence one will be in an advantageous position compared to the other party. Leitner (2006) defined financial information asymmetry as the situation where the MSMEs (borrowers) have personal knowledge about their ability to repay the loan and which the financial lending institutions(lenders) cannot be able to know. This situation causes the lending institutions to be unable to distinguish between good and bad borrowers.

\subsubsection{Type of Lending Financial Institution}

The MSMEs can get loans from commercial banks, MFIs, or Saccos. CBK (2020) defines the lending financial Institution as formal entities that extend credit to micro, small, and mediumsized enterprises categorized into commercial banks, microfinance banks/Institutions, and Saccos. The type of lending financial institution affects access to credit.

Studies show that the type of collateral and lending requirements differ, thus dictating which financial Institution the MSMEs will acquire credit from (World Bank, 2019a). Kinyua (2014) shows that MFIs and Saccos are preferred most, while Shikumo and Mwangi (2016) show that commercial bank loan uptake is slow. Commercial banks prefer to lend to businesses with accurate financial statements or records and sufficient collateral in the form of tangible assets, which are difficult for MSMEs to obtain (Ondieki et al., 2013).

\subsubsection{Credit Reference Bureau}

According to Mole and Namusonge (2016), the first known credit bureau known as Mutual Information Society was established in 1803 in London by a group of tailors to exchange references on the paying habits of their consumers. In the United States of America (USA), the authors note that the first credit bureau was established in Brooklyn in 1869. In Kenya, the Central Bank of Kenya (CBK, 2020) initiated and introduced CRB as a policy to be implemented by all commercial banks in Kenya to improve credit risk management in the banking sector.

\subsubsection{Access to Credit}

Access to credit is the ability of individuals and enterprises to obtain external funding to enable them to ease cash flow problems (Silong \& Gadanakis, 2020). Chirchir (2017) points out that lack of access to credit is universally accepted as the critical problem for MSMEs. The author highlights that credit constraint operates in various ways in Kenya, where the underdeveloped capital markets force entrepreneurs to rely on self-financing or family and friends, which is not enough to spur MSMEs operations optimally. This lack of long-term credit forces MSMEs to rely on high-cost short-term finance and even the unregulated high-risk informal sources of credit.

Chirchir (2017) indicates no structured institutional mechanisms to facilitate the flow of financial resources from the formal sector through MFIs to MSMEs in Kenya. Mutinda (2018) found out that most MSMEs are often unable to procure adequate financial resources to procure machinery, equipment, and raw materials in addition to meeting day-to-day expenses.

The main concern of this study is the external credit facilities available to MSMEs. According to Buyinza et al., (2018), external financing or credit facilities is a kind of finance provided by individuals or entities other than the proprietor or partners of the company, partnership, or sole proprietorship. Credit can be in any of the following forms; overdrafts, trade creditors, lease financing, debentures, loans, overdrafts, and can be either short-term or longterm depending on the lender's assessment of the borrowers' ability to repay.

Silong and Gadanakis (2020) have linked interest rates or cost of finance, lack of financial management skills by MSMEs, high fees charges, risk-averse behavior by MSMEs, lack of accurate financial information by MSMEs, and stringent collateral requirements as the factors that influence access to credit.

\subsection{Empirical literature review}

An empirical review of the objectives of the studies:

\subsubsection{Influence of cost of credit on access to credit for MSMEs}

Chirchir (2017) carried out a study on determinants of financial accessibility by small and medium enterprises in Eldama Ravine Sub County in Kenya. Using stratified sampling to draw a sample size of 57 respondents and Pearson correlation and regression analysis, the author found that cost of credit and access to credit had a solid negative significant correlation implying an increase in the cost of credit leads to a decrease in access to credit. Subeyr and Muturi (2017) studied factors affecting access to credit by microenterprises in Garowe in Puntland. The study used comparative and quantitative research designs. They used purposive, cluster sampling, and systematic sampling to determine respondents. The study employed Spearman and regression analysis for data analysis. The cost of credit was a significant influencer of access to credit, and the authors conclude that the cost of credit is a constraint to credit accessibility in Puntland.

Gichuki et al., (2014) carried a study in the Kangemi Harambee market in Nairobi in Kenya on challenges facing MSMEs in accessing credit facilities. They used a descriptive research design and a sample size of 241 respondents by stratified random sampling. The authors found that cost of credit was a moderate influencer of access to credit. Therefore, high transaction costs, high costs incurred in traveling to acquire the credit facilities, insurance, and legal and taxation fees impacted the access to credit, making it a challenge to access a loan.

\subsubsection{Influence of financial information asymmetry on access} to credit for MSMEs

Asongu and Odhiambo (2019) investigate the reduction of information asymmetry through information sharing on access to credit. Using the generalized method of moments technique and a sample size of 53 African Countries from 2004 - 2011, they found that information sharing avenues are significant positive predictors of access to credit.

Muli and Muli (2019) study the effect of information asymmetry on borrowing costs among microfinance clients in Kenya. The study adopted a descriptive research design. The study used primary data collected using a structured questionnaire, and multiple regression was performed on the data. It was found that financial information asymmetry was a significant positive predictor of access to credit. Specifically, borrowers' history of 
credit and information were significant predictors of access to finance. Borrowers' proximity does not influence the access to credit.

Huang et al., (2014) conducted a study in China to determine financial difficulties for SMEs using information asymmetry theories. The study adopted a comparative literature review design. It was found that information asymmetry significantly causes adverse selection and moral hazards, contributing to lending institutions' high interest rates charged on credit access. Information asymmetry causes lenders to take measures to mitigate against the high risk associated with loan default.

\subsubsection{Influence of type of lending financial Institution on access to credit for MSMEs}

Shikumo and Mwangi (2016) studied determinants of lending to small and medium enterprises by commercial banks in Kenya. The study undertook a census of the 43 commercial banks, obtaining complete data for 36 institutions. Using secondary data from the annually published reports of commercial banks in Kenya for five years, they determined that bank size and liquidity influence lending to MSMEs and that lending to SMEs by commercial banks poses the most severe credit risks. Therefore, commercial banks are reluctant to lend to MSMEs, exacerbating the problem of access to credit.

Gangata \& Matavire (2013) studied the challenges facing MSMEs with access to credit from lending institutions and established that the main reason why most MSMEs are turned down on their request to access funding from financial firms was failing to meet the lending requirements. The authors cite collateral security required by commercial banks as the primary determinant to access financing.

A study by Kinyua (2014) examined competition among lending financial institutions and easy accessibility to credit by MSMEs in Nakuru, Kenya, determined that MFIs and SACCOS were the most preferred sources of credit for MSMEs.

Commercial banks are reluctant to loan to MSMEs, citing the high risk of default. Hwarire (2012) study examined credit management and loan repayment of MSMEs in South Africa financial institutions. It concluded that $39 \%$ of loan repayments by MSMEs were not made on time, while $28 \%$ defaulted. Some studies have cited commercial banks' loan uptake as slow due to the factors they consider to grant a loan, leading to the inability of MSMEs to access funding from commercial banks.

Wangai \& Omboi (2011) analyzed the factors that influence credit demand among small-scale entrepreneurs in Meru Central Business district, Kenya. They established that household income, entrepreneur's level of education, and the number of entrepreneur's dependent factors that influence commercial banks to lend to MSMEs.

Vera and Onji (2010) state that for MSMEs to access finance from commercial banks, they need quality audited financial statements, which most MSMEs cannot have as it will increase operations costs to hire auditors. Even most of them have a poor educational background. As a result, commercial banks' rules and procedures deter MSMEs from accessing their loans.

\subsubsection{Influence of CRB on access to credit for MSMEs}

Mole and Namusonge (2016) studied the factors affecting access to credit by small and medium enterprises in Kitale municipality. The study employed a descriptive survey design and used Krejcie and Morgan formula to draw a sample size of 256
SMEs. They collected data using a questionnaire and interviews. Descriptive statistics and correlation analysis established that, among other factors, credit referencing bureau policies significantly influence access to credit facilities by SMEs from financial institutions. They recommend that information asymmetry should be enhanced between CRB and the financial institutions on the one hand and SMEs on the other hand.

Saliku (2015) studies the influence of credit reference bureaus on access to credit by small and medium enterprises in Kitale municipality in Trans Nzoia County. The findings revealed that the CRBs have policies that guide their operations and that the policies of CRBs have a significant impact on SMEs ' daily operations. The study determined that SMEs are not aware of the CRB policies lenders use to assess their viability for loans. The study highlights the suspicion with which SMEs view CRB, with a substantial proportion doubting their legality and mandate. Most SMEs have failed to benefit from CRB policies because they have defaulted on their loans and ended up being listed as serial defaulters. The listing has diminished their chances of accessing credit or increasing the cost of loans since they have low credit ratings from CRB.

\subsection{Suggestions for further research}

Upon extensive review of the existing literature, this study identifies research gaps on the effect of information, communication, and technology (ICT) on access to credit. It is established that given the nature of the modern world, computer literacy is a prerequisite to operating any business enterprise. To solve the perennial problem of access to credit, MSMEs operators must embrace ICT. Hence there is a need to understand the influence of ICT on access to credit for MSMEs.

The study was limited to determining the factors that influence access to credit for MSMEs in Ruiru Sub County in Kenya. The study found glaring gaps in access to credit which is the major driving factor for the development of the Kenyan economy. Studies should be carried out on emerging determinants of access to credit, such as the impact of global pandemics on access to credit for MSMEs, informal lending institutions' access to credit, and the impact of cryptocurrencies on access to credit for MSMEs.

\section{RESEARCH METHODOLOGY}

\subsection{Research Design}

This study adopted a descriptive research design. The choice of descriptive research design was guided by the need to collect data on various variables through detailed descriptions. It ensured that the research aim of exploring relationships was achieved (Kothari \& Garg, 2019). It was also consistent with other studies (Buyinza et al.,2018; Balogun et al., 2018; Silong \& Godanakis, 2020).

\subsection{Population}

The target population was all the 590 registered MSMEs for operation in 2021 in Ruiru Sub County. The information was obtained from Ruiru Sub-County offices located in Ruiru town in Kenya. The choice of the target population was consistent with prior researches (Chirchir, 2017, Balogun et al., 2018).

\subsection{Sampling Frame}

The sampling frame for this study was the database for the department of business registration in Ruiru Sub County in the ministry of trade of the Government of Kiambu County, archiving 
all the licensed MSMEs operators for 2021. The use of all the items in the sampling frame was consistent with prior research studies whose choice of sampling frame comprised all the listed items in the department of the relevant registration body (Buyinza et al.,2018; Balogun et al., 2018; Silong \& Godanakis, 2020).

\subsection{Sampling Design}

The study employed a probability sampling design. Saunders et al., (2019) explain that probability sampling aims to make inferences from the sample and the population to answer the research questions and meet the research objectives.

\subsubsection{Sampling Technique}

The study employed stratified random sampling. The MSMEs are made up of 3 segments in line with the working definition of MSMEs (MSE Bill, 2012). The segmentation makes for three different sectors based on the number of employees and business turnover. The MSMEs were licensed as single permit businesses. Hence, the study used the stratified sampling technique and simple random sampling to select the representative sample.

\subsubsection{Sample Size}

The study used Slovin's Formula to determine the minimum allowable sample size. Using Slovin's formulae the representative sample size was: $590 /[1+590(0.0025)]=238$.

\subsection{Research Instrument}

This study used a structured open and close-ended questionnaire, which consisted of structured questions and a fivepoint Likert scale where one was strongly disagreed, and five was strongly agree to capture the relevant information for all the variables.

\subsection{Data Collection}

This study employed primary data.

\subsection{Model Specification}

The data was transformed into a mean of variables and $\log$ 10 of transformed mean variables and tested for normality. The Kolmogorov-Smirnov for the data set showed that all the variables' values are less than 0.05 hence statistically significant. Therefore, the data was found to be non-parametric and not normally distributed (Osborne, 2017). Non-parametric data analysis techniques, ordinal regression, and Spearmen Correlation were carried out. The study adopted the ordinal regression model (Liu \& Koirala, 2012).

According to Liu and Koirala (2012), the ordinal logistic

regression equation was expressed as:
$\operatorname{Logit}\left[\pi\left(\mathrm{Y} \leq \mathrm{j} \mid \mathrm{X}_{1}, \mathrm{X}_{2} \ldots \mathrm{X}_{\mathrm{p}}\right)\right]=\mathrm{In} \quad \pi\left(\mathrm{Y} \in \mathrm{j} \mid \mathrm{X}_{1}, \mathrm{X}_{2} \ldots \mathrm{X}_{\mathrm{p}}\right) / \pi$ $\left(\mathrm{Y}>\mathrm{j} \mid \mathrm{X}_{1}, \mathrm{X}_{2} \ldots \mathrm{X}_{\mathrm{p}}\right)$

$=\alpha_{j}+\left(-\beta_{1} X_{1}-\beta_{2} X_{2}-\ldots-\beta_{p} X_{p}\right)$.

Where $\pi\left(Y \leq j \mid X 1, X_{2}, \ldots, X_{p}\right)=$ Probability of being at or below category $\mathrm{j}$, given a set of inputs, $\mathrm{j}=1,2, \ldots \mathrm{J}-1, \alpha_{\mathrm{j}}=$ Cut points or coefficients intercepts and $\beta_{1}, \beta_{2}, \ldots \beta_{\mathrm{p}}$ are logit coefficients. The model determined the odds of being beyond a certain level relative to being at or below that level. A positive logit coefficient indicated that the variable was more likely to be at a higher level than a lower level of the response variable.

\section{RESEARCH FINDINGS}

\subsection{Case Processing Summary}

According to Osborne (2017), the case processing shows the proportion of cases falling at each category of the response variable access to credit.

Table 4.1.1 Case Processing Summary Case Processing Summary

\begin{tabular}{lll}
\hline & $\mathbf{N}$ & $\begin{array}{l}\text { Marginal } \\
\text { Percentage }\end{array}$ \\
\hline AC 1.6 & 27 & $12.0 \%$ \\
1.8 & 9 & $4.0 \%$ \\
2 & 27 & $12.0 \%$ \\
2.2 & 27 & $12.0 \%$ \\
2.4 & 27 & $12.0 \%$ \\
2.8 & 9 & $4.0 \%$ \\
3.4 & 9 & $4.0 \%$ \\
3.6 & 9 & $4.0 \%$ \\
3.8 & 9 & $4.0 \%$ \\
4 & 18 & $8.0 \%$ \\
4.4 & 27 & $12.0 \%$ \\
4.6 & 27 & $12.0 \%$ \\
Valid & 225 & $100.0 \%$ \\
Missing & 0 & \\
Total & 225 & \\
\hline
\end{tabular}

Source: SPSS (2021)

According to table 4.4.1, eleven cases are falling at each level of the outcome variable access to credit.

\subsection{Tests of normality using the transformed mean of variables}

The data collected from the questionnaire was transformed by determining the mean of each variable, and it was checked for normality before performing order analysis (Osborne, (2015, 2017). Table 4.2.1 shows the results for tests of normality using the transformed mean of variables.

Table 4.2.1: Kolmogorov-Smirnova Test of Normality for the transformed mean of variables

Tests of Normality

\begin{tabular}{llll}
\hline & Statistic & df & Sig. \\
\hline AC & .227 & 225 & .000 \\
COC & .179 & 225 & .000 \\
FIA & .178 & 225 & .000 \\
TLFI & .182 & 225 & .000 \\
CRB & .157 & 225 & .000 \\
\hline
\end{tabular}

a. Lilliefors Significance Correction

Source: SPSS (2021)

The Kolmogorov-Smirnov for data set above 100 shows that all the values $(\mathrm{p}=.000)$ for the variable are less than $(\mathrm{p}=0.05)$ hence statistically significant. The Kolmogorov-Smirnov results should not be statistically significant (Osborne, (2015, 2017). Therefore, the data was not normally distributed.

4.3 Tests of normality using $\log 10$ of the transformed variables 
Since the data was not normally distributed, we further determined $\log 10$ of the transformed variables (Osborne, (2015, 2017). Table 4.3.1 presents the results for tests of normality for Log transformed values for all variables.

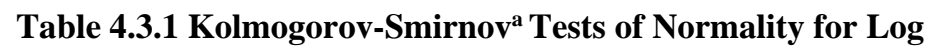
10 of Transformed Variables

Tests of Normality

\begin{tabular}{llll}
\hline & Statistic & df & Sig. \\
\hline Log_AC & .179 & 225 & .000 \\
Log_COC & .168 & 225 & .000 \\
Log_FIA & .171 & 225 & .000 \\
Log_TLFI & .169 & 225 & .000 \\
Log_CRB & .117 & 225 & .000 \\
\hline
\end{tabular}

a. Lilliefors Significance Correction

Source: SPSS (2021)
According to table 4.3.1, the Log transformed values ( $\mathrm{p}=$ $0.000)$ for all the variables were less than $(\mathrm{p}=0.05)$, which shows that they are statistically significant hence not normally distributed.

Since the Kolmogorov-Smirnov results for both means of transformed variable and Log 10 of transformed variables are statistically significant, the data collected from the questionnaire is not normally distributed; hence the study performed nonparametric data analysis techniques, which are ordinal regression analysis and Spearmen Correlation analysis (Osborne, 2015, 2017).

\subsection{Correlational Analysis}

According to the normality tests, as shown in table 4.1.1 and table 4.2.1, the data set is not normally distributed; hence the study performs non-parametric correlation analysis using Spearman Correlation (Osborne, 2015, 2017). Table 4.4.1 shows the nonparametric correlations results for the data set.

Table 4.4.1 Non-parametric Correlations

\begin{tabular}{|c|c|c|c|c|c|}
\hline & $\mathrm{AC}$ & $\mathrm{COC}$ & FIA & TLFI & $\mathrm{CRB}$ \\
\hline Spearman's rho AC Correlation & 1.000 & $.971^{* *}$ & $.974 * *$ & $.968 * *$ & $.961 * *$ \\
\hline Coefficient & & & & & \\
\hline Sig.(2-tailed) & & .000 & .000 & .000 & .000 \\
\hline $\mathrm{N}$ & 225 & 225 & 225 & 225 & 225 \\
\hline $\begin{array}{r}\text { COC Correlation } \\
\text { Coefficient }\end{array}$ & $.971 * *$ & 1.000 & $.997 * *$ & $.995^{* *}$ & $.919 * *$ \\
\hline $\begin{array}{l}\text { Coefficient } \\
\text { Sig. (2-tailed) }\end{array}$ & .000 & & .000 & .000 & .000 \\
\hline $\mathrm{N}$ & 225 & 225 & 225 & 225 & 225 \\
\hline $\begin{array}{r}\text { FIA Correlation } \\
\text { Coefficient }\end{array}$ & $.968 * *$ & $.995 * *$ & $.998 * *$ & 1.000 & $.917 * *$ \\
\hline Sig. (2-tailed) & .000 & .000 & .000 & .000 & .000 \\
\hline $\mathrm{N}$ & 225 & 225 & 225 & 225 & 225 \\
\hline $\begin{array}{r}\text { TLFI Correlation } \\
\text { Coefficient }\end{array}$ & $.968 * *$ & $.995 * *$ & $.998 * *$ & 1.000 & $.917 * *$ \\
\hline Sig. (2-tailed) & .000 & .000 & .000 & & .000 \\
\hline $\mathrm{N}$ & 225 & 225 & 225 & 225 & 225 \\
\hline $\begin{array}{l}\text { CRB Correlation } \\
\text { Coefficient }\end{array}$ & $.961 * *$ & $.919 * *$ & $.920 * *$ & $.917 * *$ & 1.000 \\
\hline Sig. (2-tailed) & .000 & .000 & .000 & .000 & \\
\hline $\mathrm{N}$ & 225 & 225 & 225 & 225 & 225 \\
\hline
\end{tabular}

**. Correlation is significant at the level 0.01 level(2-tailed)

\section{Source: SPSS (2021)}

4.4.1 Correlation between Cost of credit and access to credit.

According to table 4.4.1, Spearman's Correlation between the cost of credit and access to credit was 0.971 , which shows a high correlation between the two variables and was found to be statistically significant with a significant value of .000 , which was less than 0.05 .

\subsection{2: Correlation between financial information asymmetry and access to credit}

According to table 4.4.1, Spearman's correlation between the financial information asymmetry and access to credit was 0.974 , which shows a high correlation that was statistically significant at a significant value of less than 0.05 . 


\subsubsection{Correlation between type of financial lending institution and access to credit}

According to table 4.4.1, Spearman's correlation between the type of financial lending institution and access to credit was 0.968 , which shows a high correlation that was statistically significant with a significant value of less than 0.05 .

\subsubsection{Correlation between credit reference bureau and access to credit}

According to table 4.4.1, Spearman's correlation between credit reference bureau and access to credit was 0.961 , which shows a high correlation that is statistically significant with a significant value of .000 , which is less than 0.05 .

\subsection{Ordinal Regression Analysis (ORL)}

According to the normality tests, as shown in table 4.1.1 and table 4.1.2, the data set is not normally distributed, and therefore non-parametric data analysis was performed. Osborne (2015, 2017) notes that ordinal regression analysis is employed when there are two categories for the dependent variables that are ordered. This study uses a five-point Likert scale with five types. The ORL yields only a single set of regression coefficients to estimate the relationships between independent and dependent variables. The study performed ordinal regression analysis to show the relationship between the variables.

\subsection{1: Model fitting information}

Model fitting information shows the -2 Log-likelihood for an intercept only (or null) model and the full model, which contains the complete set of inputs (Osborne, 2017). The author further points out that a likelihood ratio chi-square test is carried out to test whether there is a significant improvement in the fit of the final model relative to the intercept-only model. Table 4.5.1 shows the results for model fitting information

\section{Table 4.5.1.1: Model fitting Information Model Fitting Information}

\begin{tabular}{lllll}
\hline Model & $\begin{array}{l}\mathbf{- 2} \text { Likelihood } \\
\text { Log }\end{array}$ & $\begin{array}{l}\text { Chi- } \\
\text { Square }\end{array}$ & df & Sig. \\
\hline $\begin{array}{l}\text { Intercept } \\
\text { Only }\end{array}$ & 1067.590 & & & \\
Final & .000 & 1067.590 & 4 & .000 \\
\hline
\end{tabular}

Link Function: Logit

Source: SPSS (2021)

According to table 4.5.1.1, the model relevant information for the study, there is a statistically significant improvement in the fit of the final model over the null model $\left[X^{2}(4)=1067.59\right.$, $\mathrm{p}<.001]$. We conclude that the data collected fits the model very well.

\subsection{2: Goodness of Fit}

Osborne (2017) notes that the Goodness of fit table contains the deviance and Pearson chi-square tests, which help determine if the model exhibits a good fit to the data. Field (2018) shows that non-significant tests results show that the model fits the data well. Table 4.5.2.1 shows the Goodness of fit results
Table 4.5.2.1: Goodness of Fit Goodness-of-fit

\begin{tabular}{llll}
\hline & Chi-Square & df & Sig. \\
\hline Pearson & 188.344 & 216 & .913 \\
Deviance & 201.502 & 216 & .752 \\
\hline Link
\end{tabular}

Link function: Logit

Source: SPSS (2021)

According to the findings presented on table 4.5.2.1, the Pearson chi-square test is $\left[\mathrm{X}^{2}(216)=188.344, \mathrm{p}=.913\right]$ and the deviance test is $\left[\mathrm{X}^{2}(216)=201.502, \mathrm{p}=.752\right]$. This implies that the model fits the data very well.

\subsection{3: Pseudo R-Square}

Pseudo R-Square is used to indicate the percent changes in the dependent variable due to independent variables (Osborne,2017). Table 4.5.3.1 shows the results of Pseudo RSquare for the data collected.

\section{Table 4.5.3.1 Pseudo R-Square Pseudo R-Square}

\begin{tabular}{ll}
\hline Cox and Snell & .991 \\
Nagelkerke & 1.000 \\
McFadden & 1.000 \\
\hline
\end{tabular}

Link function: Logit.

Source: SPSS (2021)

According to table 4.5.3.1, the Nagelkerke of the collected data is 1.000 , which implies that $100 \%$ changes in access to credit result from cost of credit, financial information asymmetry, type of financial lending institution, and credit reference bureau (Field, 2018).

\subsection{4: Test of parallel lines}

Osborne $(2015,2017)$ note that the proportional odds assumption essentially states that the relationship between the independent variable is the same across all possible comparisons involving the response variable. The author notes that the nonsignificance results indicate that the test of parallel lines is satisfied. Table 4.5.4.1 shows the results for the test of parallel lines.

Table 4.5.4.1 Test of parallel lines Test of Parallel Lines

\begin{tabular}{lllll}
\hline Model & $\begin{array}{l}\mathbf{- 2} \\
\text { Likelihood }\end{array}$ & $\begin{array}{l}\text { Chi- } \\
\text { Square }\end{array}$ & df & Sig. \\
\hline $\begin{array}{l}\text { Null } \\
\text { Hypothesis }\end{array}$ & .000 & & & \\
General & .000 & .000 & 40 & 1.000 \\
\hline
\end{tabular}

Link function: Logit

Source: SPSS (2021)

According to table 4.5.4.1 results, the proportional odds assumption is satisfied as $p=1.000$ (Osborne, 2015, 2017) 


\subsubsection{Parameter estimates}

According to Osborne (2017) parameter estimates table shows the regression coefficients and significance tests for each of the predictor variables in the model. The author points out that the regression coefficients were interpreted as the predicted change in $\log$ odds of being higher instead of a lower category on the outcome variable while controlling for the remaining predictor variables per unit increase on the explanatory variable.

The positive estimate was interpreted to mean that for every one-unit increase on an explanatory variable, there is a predicted increase of a certain amount in the Log odds of falling at a higher category of the response variable. The positive estimate indicates that as scores increase on a predictor variable, there is an increased probability of falling at a higher class on the output variable.
According to Osborne (2017), the negative estimates were interpreted as every one-unit increase on an explanatory variable; there is a predicted decrease of a certain amount in the Log odds of falling at a higher category of the outcome variable. The negative estimates mean that as scores increase on the predictor variable, there is a decreased probability of falling at a higher class on the response variable. Osborne (2017) note that the threshold estimates given in the parameter estimates table are intercepts and can be interpreted as the log odds of being in a particular category or lower when scores on the other variables are zero. Table 4.5.5.1 shows the results of the parameter estimates.

\section{Table 4.5.5.1 Parameter Estimates}

\section{Parameter Estimates}

\begin{tabular}{|c|c|c|c|c|c|c|c|c|}
\hline & Estimate & $\begin{array}{l}\text { Std. } \\
\text { Error }\end{array}$ & Wald & df & Sig. & $\begin{array}{lr}95 \% \quad \text { Confidence } \\
\text { Interval } \\
\text { Bound) }\end{array}$ & $\begin{array}{l}95 \% \\
\text { interval } \\
\text { Bound) }\end{array}$ & $\begin{array}{r}\text { Confidence } \\
\text { (Upper }\end{array}$ \\
\hline Threshold [AC $=1.60]$ & 31.236 & 3.136 & 99.233 & 1 & .000 & 25.090 & 37.382 & \\
\hline$[\mathrm{AC}=1.80]$ & 32.900 & 3.260 & 101.820 & 1 & .000 & 26.509 & 39.290 & \\
\hline$[\mathrm{AC}=2.00]$ & 35.990 & 3.344 & 115.843 & 1 & .000 & 29.436 & 42.544 & \\
\hline$[\mathrm{AC}=2.20]$ & 43.511 & 4.256 & 104.507 & 1 & .000 & 35.169 & 51.853 & \\
\hline$[\mathrm{AC}=2.40]$ & 52.537 & 5.462 & 92.510 & 1 & .000 & 41.831 & 63.243 & \\
\hline$[\mathrm{AC}=2.80]$ & 59.131 & 5.894 & 100.650 & 1 & .000 & 47.579 & 70.683 & \\
\hline$[\mathrm{AC}=3.40]$ & 63.127 & 6.185 & 104.162 & 1 & .000 & 51.004 & 75.250 & \\
\hline$[\mathrm{AC}=3.60]$ & 64.726 & 6.233 & 107.835 & 1 & .000 & 52.509 & 76.942 & \\
\hline$[\mathrm{AC}=3.80]$ & 67.598 & 6.540 & 106.849 & 1 & .000 & 54.781 & 80.416 & \\
\hline$[\mathrm{AC}=4.00]$ & 75.002 & 7.326 & 104.812 & 1 & .000 & 60.644 & 89.361 & \\
\hline$[\mathrm{AC}=4.40]$ & 80.157 & 7.717 & 107.889 & 1 & .000 & 65.032 & 95.282 & \\
\hline Location COC & -5.919 & 4.244 & 1.945 & 1 & .163 & -14.236 & 2.399 & \\
\hline FIA & 42.344 & 6.831 & 38.428 & 1 & .000 & 28.956 & 55.732 & \\
\hline TLFI & -25.731 & 4.111 & 39.173 & 1 & .000 & -33.789 & -17.673 & \\
\hline CRB & 7.633 & .808 & 89.244 & 1 & .000 & 6.049 & 9.216 & \\
\hline
\end{tabular}

Link function: Logit

\section{Source: SPSS (2021)}

Using the study's predictive model, we can determine our predictive model values from table 4.5.5.1. The relationship between the determinants of access to credit for MSMEs in Ruiru Sub County can be modeled (Liu and Koirala, 2012): Ordinal logistic regression uses Log-odds of cumulative probabilities.

$\mathrm{F}_{\mathrm{j}}(\mathrm{X})=\mathrm{P}\left(\mathrm{Y} \leq_{\mathrm{j}} \mid \mathrm{X}\right)$

$\mathrm{L}_{\mathrm{j}}(\mathrm{X})=\operatorname{logit}\left(\mathrm{F}_{\mathrm{j}}(\mathrm{X})\right)=\log \left(\left(\mathrm{F}_{\mathrm{j}}(\mathrm{X}) /\left(1-\left(\left(\mathrm{F}_{\mathrm{j}}(\mathrm{X})\right)\right.\right.\right.\right.$

Model regression equation:

$L_{j}(X)=\alpha_{j}-\beta_{1} X_{1}-\beta_{2} X_{2}-\ldots-\beta_{p} X_{p}$

Where $\left(\mathrm{Y} \leq \mathrm{j} \mid \mathrm{X} 1, \mathrm{X}_{2}, \ldots, \mathrm{X}_{\mathrm{p}}\right)=$ Probability of being at or below category $\mathrm{j}$, given a set of inputs, $\mathrm{j}=1,2, \ldots \mathrm{J}-1, \alpha_{\mathrm{j}}=$ Cut points or coefficients intercepts and $\beta_{1}, \beta_{2}, \ldots \beta_{\mathrm{p}}$ are logit coefficients and the probability of being in at least the highest category is 1 ,

Logit $\left(\mathrm{F}_{\text {Strongly Disagree }}\right)=32.9+42.344 \mathrm{COC}-42.344 \mathrm{FIA}+25.731$ TLFI - 7.633CRB

Logit $\left(\mathrm{F}_{\text {Strongly Agree }}\right)=80.157+42.344 \mathrm{COC}-42.344 \mathrm{FIA}+25.731$ TLFI - 7.633CRB

Where:

$\mathrm{COC}=$ Cost of credit

FIA $=$ Financial information asymmetry
TLFI $=$ Type of lending financial institution $\mathrm{CRB}=$ Credit reference bureau

\section{CONCLUSIONS}

The first objective sought to determine the influence of the cost of credit on access to credit for MSMEs in Ruiru Sub County in Kenya. The correlation between the cost of credit and access to credit [ $0.971, \mathrm{p}=0.000]$ showed a high relationship between access to credit and the cost of credit. From the correlation results, we conclude that there is an association between the changes in the cost of credit and access to credit. The parameter estimates showed that cost of credit Estimate $=-5.919, p=1.63]$ was not a significant negative predictor for access to credit. Hence, we can conclude that there is not sufficient evidence to conclude that increase in the cost of credit will result in a decrease in access to credit.

The study's second objective sought to determine the influence of financial information asymmetry on access to credit 
for MSMEs in Ruiru Sub County in Kenya. The correlation between financial information asymmetry and access to credit $[0.974, p=0.000]$ was high; hence we conclude that the changes in financial information asymmetry cause the differences in access to credit. The estimator parameters show that financial information asymmetry was a significant positive estimator of access to credit [estimate $=42.344, \mathrm{p}=0.000$ ]. Hence, we conclude that an increase in financial information asymmetry increases access to credit. The biasness in the information markets causes the MSMEs not to access credit.

The third objective of the study was to determine the influence of the type of financial lending institution on access to credit for MSMEs in Ruiru Sub County in Kenya. The correlation between lending financial institutions and access to credit was [ $0.968, p=0.000]$. We conclude that there is a strong significant correlation between the variables. The changes in types of lending institutions influence changes in access to credit. The parameter estimates show that type of lending institution was a significant negative predictor of access to credit [ Estimator $=-25.731, \mathrm{p}=$ $0.000]$. We conclude that as the type of lending financial institution increases, the access to credit reduces. Hence the indicators of the type of lending financial institution affect the access to credit.

The fourth objective of the study was to determine the influence of the credit reference bureau on access to credit for MSMEs in Ruiru Sub County in Kenya. The correlation results for credit reference bureau and access to credit [ $0.961, p=0.000$ ] were high. We conclude that there is an association between the changes in the credit reference bureau and changes in access to credit. The ordinal regression coefficient shows that credit reference is a significant predictor of access to credit [Estimator $=$ $7.633, p=0.000]$. Therefore, we conclude that changes in credit reference bureau indicators cause an increase in access to credit for MSMEs in Ruiru Sub County. Credit reference bureau influences access to credit.

\section{RECOMMENDATIONS}

The study sought to determine the factors that influence access to credit for MSMEs in Ruiru Sub County in Kenya. From the summary and conclusions of the study, the study recommends from the objective of determining the influence of cost of credit on access to credit which was found to be statistically insignificant, that the financial institutions work towards lowering the cost of credit to enable MSMEs to gain access to access credit. From the second objective of influence of financial information asymmetry, the study recommends that the problem of financial asymmetry can be resolved by both parties adhering to proper financial disclosures practices, financial institutions to increase training concerning the products they are offering the market and to increase transparency in the process of a loan application.

From the third objective of influence of the type of financial lending institution. The study recommends that SACCOs, microfinance, and commercial banks align their lending terms to standardize the lending process across all lending institutions. The study also recommends that financial institutions customize their credit products to specific target markets, such as developing loan products targeting micro-enterprises or medium enterprises since they exhibit different credit needs.
From the fourth objective of influence of credit reference bureau, the study recommends that credit reference role should be to increase access to credit rather than cause loss of access to credit as the case is currently. The credit reference bureau should be restructured to suit the emerging market's needs rather than replicating a developed market model in the emerging economies. The study further recommends credit reference bureau ensure that they provide up-to-date credit information regarding MSMEs to stop being a hindrance to access to credit.

\section{REFERENCES}

[1] African Development Bank and Government of Kenya. (2018). The State of Kenya's Private Sector. African Development Bank and Government of Kenya.

[2] Akerlof, G. A. (1970). The market for lemons: Quality uncertainty and the market mechanism. The Quarterly Journal of Economics, 84(3), 488-500.

[3] Andries, A. M., \& Cuza, A. I. (2009). Theories Regarding Financial Intermediation and Financial Intermediaries - A Survey. The Annals of the "Ştefan cel Mare," 9 (2), 254- 261.

[4] Asongu, S., \& Odhiambo, N. M. (2018). Information asymmetry, financialization, and financial access. International Finance. DOI: $10.2139 /$ ssrn.3180506

[5] Balogun, O., Agumba, J., \& Ansary. N. (2018). Evaluating credit accessibility predictors among small and medium contractors in the South African construction industry. Acta Structilia, 25(2), 6993. https://dx.doi.org/10.18820/24150487/as25i2.3

[6] Buyinza, F., Tibaingana, A., \& Mutenyo, J. (2018). Factors affecting access to formal credit by micro and small enterprises in Uganda. Institute for Comprehensive Analysis of the Economy, Working Paper Serie-No 83.

[7] Central Bank of Kenya (2020) Bank Supervision Annual Report 2009 Retrieved on August 2020 https://www.centralbank.go.ke/images/docs/Bank\%20Supervision\%20Repo rts/Annual\%20Reports/bsd2020B.pdf

[8] Chirchir, S.J. (2017). Determinants of financial accessibility by small and medium enterprises in Eldama Ravine Sub - County, Kenya; Unpublished MBA, Jomo Kenyatta University of Agriculture and Technology.

[9] Field, A. (2018). Discovering statistics using IBM SPSS statistics $\left(5^{\text {th }}\right.$ ed) Los Angeles: Sage.

[10] Gangata, K., \& Matavire, E. M. (2013). Challenges facing SMEs in accessing finance from financial institutions: The case of Bulawayo, Zimbabwe, International Journal of Applied Research and Studies, 2(7).

[11] Gichuki, W., Njeru, A., \& Tirimba. O. (2014). Challenges facing micro and small enterprises in accessing credit facilities in Kangemi Harambee market in Nairobi County, Kenya. International Journal of Scientific and Research Publications, 4(12). 1-15.

[12] Government of Kenya. (2012). The Micro and Small Enterprises Act 2012 Kenya Gazette Supplement No. 219 (Acts No.55). Nairobi, Government Printer, Government of Kenya.

[13] Government of Kenya., (2007). Vision 2030. Nairobi, Government Printer, Government of Kenya.

[14] Huang, C., When, Y. and Liu, Z. (2014). Analysis on financing difficulties for SMEs due to asymmetric information. Global Disclosure of Economics and Business, 3(2) ISSN 2305-9168

[15] Hwarire, C. (2012). Loan repayment and credit management of small businesses: A case study of a South African commercial bank. A paper presented at the African Development Finance Workshop 7-8 August 2012. Cape Town, South Africa.

[16] Kinyua, A. N., (2014). Factors affecting the performance of small and medium enterprises in the Jua Kali sector in Nakuru town, Kenya. Unpublished MBA project. Egerton University.

[17] KIPPRA. (2020). Review of government Policies for the promotion of Micro and Small-Scale Enterprises. Nairobi: Kenya Institute for Public Policy Research Analysis.

[18] KNBS (2018). Economic Survey 2018. Nairobi, Kenya National Bureau of Statistics, Government Printer. 
[19] Kweyu, N. M. (2017). Determinants of access to credit by women-owned SMEs in Migori Town, Kenya. Unpublished MBA project. United States International University-Africa.

[20] Leitner, Y. (2006). Using collateral to secure loans. Federal Reserve Bank of Philadelphia Business Review, Q2, 9-16.

[21] Liu, X \& Koirala. H. (2012). Ordinal regression analysis: Using generalized ordinal logistic regression models to estimate educational data. Journal of Modern Applied Statistical Methods. 11(1). doi: $10.22237 / \mathrm{jmasm} / 1335846000$

[22] Micro and Small Enterprises Bill, (2012) Retrieved on August 20 2020 from: http://www.industrialization.go.ke/index.php/policies.

[23] Mole, A. \& Namusonge, G. S. (2016). Factors affecting access to credit by SMEs; A case of Kitale town. International Journal of Social Sciences and Humanities Invention, 3(10), 2904-2917.

[24] Muli, E.N., \& Muli. W.M. (2019). Effects of information asymmetry on borrowing cost among microfinance in Kenya. International Journal of Economics, Commerce, and Management. 7(8), 440 - 472.

[25] Mutinda, A. K. (2019). Financial factors affecting access to credit among small and medium enterprises in Machakos town Sub County in Kenya. Unpublished Master of business administration. South Eastern Kenya University.

[26] Ndungu, C. W. (2016). Factors affecting credit access among small and medium enterprises in Murang's County. Unpublished MBA project. The University of Nairobi.

[27] Ondieki, N. S., Nashappi, N. G., \& Moraa, O. S. (2013). Factors that determine the capital structure among micro-enterprises: A case study of micro-enterprises in Kisii town, American International Journal of Contemporary Research, 3(7).

[28] Osborne, J.W. (2015). Best practices in logistic regression. Los Angeles: Sage.

[29]

[30] Osborne, J.W. (2017). Regression and linear modeling: best practices and modern methods. Thousand Oaks, CA: Sage

[31] Saliku, M. (2015). Influence of credit reference bureaus on access to credit by small and medium enterprises in Kitale Municipality, Trans Nzoia County. Unpublished MBA project. The University of Nairobi.
[32] Saunders, M., Lewis, P., \& Thornhill, A. (2019). Research methods for business students. $8^{\text {th }}$ ed. New York, New York: Pearson.

[33] Shikumo, D. H., \& Mwangi, M. (2016). Determinants of lending to small and medium enterprises by commercial banks in Kenya, 7(4), 57-63.

[34] Silong, A. \& Gadanakis, Y. (2020) Credit sources, access and factors influencing credit demand among rural livestock farmers in Nigeria. Agricultural Finance Review, 80 (1). 68-90.

[35] Stiglitz, J. E., \& Weiss, A. (1981). Credit rationing in markets with imperfect information. The American economic review, 71(3), 393-410.

[36] Subeyr, M. H., \& Muturi. (2017). Factors affecting access to credit by microenterprises in Garowe, Puntland. International Journal of Economics, Commerce, and Management, 5(3).

[37] Vera, D., \& Onji, K. (2010). Changes in the banking system and small business lending. Small Business Economics, 34(3), 293-308.

[38] Wangai, P. N., \& Omboi, B. M. (2011). Factors that influence the demand for credit among small-scale investors: A case study of Meru Central District, Kenya. Research Journal of Finance and Accounting, 18-20.

[39] World Bank. (2019a). Doing business 2018: Understanding regulations for small and medium-sized Enterprises. Washington, DC, World Bank Group.

[40] World Bank. (2019b). Doing business 2019: Training for reform. Washington DC, World Bank Group.

[41] World Bank. (2020). Doing Business 2020: Comparing business regulation in 190 economies. Washington DC, World Bank Group.

\section{AUTHORS}

First Author - Samson Manjuru Mburu, Student, Jomo Kenyatta University of Agriculture and Technology, Kenya Second Author - Dr. Lucy Wanjiru Njogu, Ph.D., Lecturer, College of Human Resource Development (COHRED), Jomo Kenyatta University of Agriculture and Technology, Kenya 